\title{
PERSEPSI PESERTA DAN STAFF KEPEGAWAIAN TERHADAP EFEKTIVITAS PROGRAM PENDIDIKAN DAN LATIHAN PENYETARAAN PUSTAKAWAN DI PERPUSTAKAAN NASIONAL KALIMANTAN SELATAN.
}

\author{
Oleh Muhammad ); Warsito Utomo**); Ratminto**)
}

\begin{abstract}
The Response of Participant and Their Managing Personnel of Parent Organization/Institutions on the Effectiveness of Level Equality Short Education and Training Program for Librarian

Held by National Library of South Kalimantan Province
\end{abstract}

Level equality short education and training program for librarians is a short course that aims at adding the number of librarian functional employment deriving from Civil Government Employees that have a background of nonlibrary education. The employees. Therefore its effectiveness should be informed.

This writing explains the effectiveness of level equality short education and training program for librarian based on the responds of participant and their Managing Personnel of Parents Organizations/Institutions whether or not this short course is effective according to their perception. The effectiveness of this short course is marked by the occurrence or no occurrence of participant's skill, knowledge, and performance improvement as the indicators influenced. While the influencing indicators are curriculum suitability, instructors ability and treatment to participants.

The result of the research showed that there were different perceptions among the participants and their Managing Personnel of Parent Organizations/Institutions. The participants stated that this short course was not effective while their Managing Personnel of Parent Organization/Institutions stated that this short course was effective. This difference happened since, according to the participant's perception, there was no significant improvement to skill and knowledge.

Key words: Effectiveness; Education and Training Program

*) Librarian, National Library of South Kalimantan Province

**) Teaching Staff of the Faculty of Social and Political Sciences, Gadjah Mada University

\section{ABSTRAK}

Program pendidikan dan pelatihan singkat untuk penyetaraan dan fungsionalisasi pustakawan ditujukan bagi pegawai negeri sipil yang mempunyai latar belakang bukan dari pendidikan perpustakaan.

Penelitian ini menerangkan efektivitas program tingkat pendidikan dan latihan pustakawan. Efektivitas juga menunjuk pada evaluasi terhadap proses dan untuk mencapai tujuan. Efektivitas diklat dipengaruhi oleh berbagai faktor seperti peserta, tujuan, kurikulum, metode, penatar, sarana dan prasarana, monitoring, dan evaluasi.

Hasil penelitian menunjukkan bahwa perbedaan persepsi antara peserta dam pimpinan lembaga/instansi pengirim. Peserta diklat mempunyai persepsi tidak efektif, sementara menurut pimpinan lembaga/instansi mempunyai persepsi efektif. Pernyataan efektif juga didukung oleh persepsi yang diberikan oleh teman kerja peserta. Pernyataan peserta yang menilai diklat tidak efektif mènunjukkan bahwa diklat ini belum signifikan dapat meningkatkan ketrampilan dan pengetahuannya. Alasannya peserta belum mampu melaksanakan tugas-tugas kepustakawanan dengan lancar dan materi pelajaran dinilai terlalu teoritis.

Key words: Efektivitas - kualitas diklat - pustakawan

*) Pustakawan Perpustakaan Nasional Propinsi Kalimantan Selatan

**) Dosen Fakultas Ilmu Sosial dan Ilmu Politik Universitas Gadjah Mada 


\section{LATAR BELAKANG}

Salah satu lembaga pemerintah yang melaksanakan tugas untuk mengembangkan tenaga perpustakaan dan kerjasama antar badan/lembaga termasuk perpustakaan dalam maupun luar negeri adalah Perpustakaan Nasional RI. Lembaga ini dibentuk dengan Surat Keputusan Presiden nomor 11 tahun 1989 dan diperbaharui dengan Surat Keputusan Presiden nomor 50 tahun 1997.

Sebelum keluarnya Undang-Undang nomor 22 tahun 1999 tentang Pemerintah Daerah, Perpustakaan Nasional RI mempunyai instansi vertikal di setiap ibukota provinsi yaitu Perpustakaan Nasional Provinsi. Tugas yang diemban oleh Perpustakaan Nasional Provinsi hampir sama dengan tugas Perpustakaan Nasional RI, hanya ruang lingkupnya saja yang berbeda, seperti yang termuat dalam Surat Keputusan Kepala Perpustakaan Nasional RI nomor 44 tahun 1998 tanggal 23 Juli 1998, pasal 94 disebutkan bahwa Perpustakaan Nasional Provinsi menyelenggarakan fungsi; pengembangan, pembinaan, dan pendayagunaan semua jenis perpustakaan di provinsi, menyelenggarakan pendidikan dan latihan, serta pembinaan sumber daya manusia di bidang perpustakaan (Perpustakaan Nasional RI, 1998).

Salah satu aspek yang sering disorot tentang lemahnya kinerja perpustakaan di Indonesia antara lain rendahnya kualitas dan kuantitas pustakawan. Menurut data sampai saat ini terdapat hampir 300.000 perpustakaan yang terdiri dari perpustakaan sekolah sebanyak 200.000 perpustakaan diantaranya 120.000 adalah perpustakaan sekolah dasar dan hanya $1 \%$ yang memenuhi standar (Mahladi, 2000). Kondisi ini diperparah dengan minimnya tenaga fungsional pustakawan yang sampai saat ini tercatat 4.000 orang tenaga fungsional pustakawan. Apabila jumlah ini dibandingkan dengan jumlah perpustakaan sebanyak 300.000 perpustakaan, maka hanya $43 \%$ perpustakaan yang memiliki pustakawan fungsional. Apabila dikaji lebih jauh dari 4.000 orang tenaga fungsional tersebut, maka hanya ada 1.500 orang yang benarbenar berlatar belakang pendidikan formal ilmu perpustakaan, dan selebihnya mereka itu tergolong pustakawan pemutihan/ impassing pada tahun 1990 sampai 1991 (Hernandono, 1999).

Di Indonesia setiap tahun lembaga pendidikan formal yang menyelenggarakan pendidikan ilmu perpustakaan telah menghasilkan sekitar 300 sampai 400 lulusan setingkat diploma, S1, dan S2. Sedangkan perpustakaan di Indonesia memerlukan lebih banyak lagi penambahan pustakawan yang profesional. Apabila kondisi ini tidak mendapatkan perhatian, maka mungkin dalam jangka waktu sekitar 30 - 40 tahun kebutuhan tenaga profesional itu baru terpenuhi.

Salah satu upaya yang dilakukan Perpustakaan Nasional RI dan Perpustakaan Nasional Provinsi (sekarang Badan Perpustakaan \& Arsip Daerah) untuk meningkatkan kuantitas dan kualitas pustakawan ialah dengan penyelenggaraan pendidikan dan pelatihan/DIKLAT yang bernama Diklat Penyetaraan Pustakawan. Diklat ini terselenggara berdasarkan SK MENPAN No. 33 tahun 1998 tentang Jabatan Fungsional Pustakawan dan Angka Kreditnya. Dalam keputusan ini disebutkan bahwa untuk pengangkatan pertama dalam jabatan pustakawan disyaratkan mereka yang berstatus Pegawai Negeri Sipil dan serendahrendahya berijazah Diploma II perpustakaan, dokumentasi, dan informasi untuk jabatan Asisten Pustakawan. Bagi jabatan Pustakawan, disyaratkan serendah-rendahnya berijasah Sarjana strata satu (S1) bidang perpustakaan, dokumentasi, dan informasi. Kemudian bagi PNS yang memiliki ijasah strata satu (S1) non perpustakaan, dokumentasi, dan informasi diharuskan mengikuti Diklat penyetaraan di bidang perpustakaan, dokumentasi, dan informasi dan memperoleh sertifikat yang disetarakan oleh Perpustakaan Nasional R.I. (Perpustakaan Nasional RI., 2000). 
Beberapa alasan perlunya penelitian tentang pelaksanaan DIKLAT ini antara lain:

1. Diklat ini merupakan program baru yang dilaksånakan oleh Perpustakaan Nasional RI dan Perpustakaan Nasional Provinsi yang perlu diketahui efektivitasnya

2. Di seluruh Indonesia hanya 7 Perpustakaan Nasional Provinsi (Jawa Barat, Jawa Tengah, Daerah Istimewa Yogyakarta, Jawa Timur, Sumatera Selatan, Sulawesi Selatan, dan Kalimantan Selatan) yang menyelenggarakan Diklat, sehingga pengalaman penyelenggaraan itu dapat disebarluaskan ke provinsi provinsi lain.

\section{RUMUSAN MASALAH}

Fokus masalah yang akan dijelaskan dalam tulisan ini adalah:

1. Bagaimana persepsi peserta dan pimpinan lembaga/ instansi pengirim terhadap efektivitas Diklat Penyetaraan Pustakawan itu?

2. Apakah hasil Diklat itu berpengaruh terhadap peningkatan ketrampilan, pengetahuan, dan perubahan kinerja peserta?.

\section{KERANGKA TEORI}

Persepsi menurut beberapa pakar psikologi adalah proses untuk mengingat atau mengidentifikasi sesuatu, dan juga untuk persepsi rasa, bila benda yang diingat atau diidentitaskan adalah obyek yang mempengaruhi perasaan (Drever, 1988), sedangkan Kartono (1990) merumuskan persepsi sebagai pengamatan global belum disertai kesadaran, sedangkan obyek dan subjeknya belum terbedakan satu dari lainya (baru ada proses memiliki tanggapan). Untuk itu dapat ditegaskan bahwa yang dimaksud dengan persepsi dalam pengertian ini adalah tanggapan peserta dan pimpinan lembaga/instansi pengirim terhadap efektivitas Diklat
Penyetaraan Pustakawan pada Perpustakaan Nasional Kalimantan Selatan.

Dalam penelitian ini juga perlu dipahami tentang pengertian efektivitas. Efektivitas biasanya dikaitkan dengan pencapaian sasaran yang telah ditentukan Windham dan Rahmatia (1999). Efektivitas juga menunjuk pada evaluasi terhadap proses yang telah dihasilkan suatu keluaran yang dapat diamati. Efektivitas suatu pengajaran sangat penting apabila pendidikan diarahkan untuk mencapai tujuan khusus. Dengan demikian efektivitas dalam pengertian ini adalah tercapai tidaknya tujuan Diklat Penyetaraan Pustakawan yang ditandai dengan ada tidaknya peningkatan ketrampilan, pengetahuan, dan perubahan kinerja peserta.

Efektivitas Diklat banyak dipengaruhi oleh berbagai faktor seperti peserta, tujuan, kurikulum, metode, penatar, sarana prasarana, monitoring, evaluasi, dan lainnya. Sedangkan faktor pemanfaatan lulusan merupakan salah satu faktor yang mempengaruhi efektivitas Diklat.

Adapun faktor kesesuaian kurikulum menjadi sangat dominan dalam pencapaian efektivitas Diklat. Di dalam kurikulum itu harus tergambar tujuan yang ingin dicapai yakni:

1. Untuk mengembangkan keahlian dan ketrampilan peserta

2. Untuk mengembangkan pengetahuan sehingga pekerjaan dapat diselesaikan secara rasional

3. Untuk mengembangkan sikap sehingga menimbulkan kemauan kerjasama dengan temanteman pegawai dan manajer (Moekijat, 1991)

Kemampuan pengajar juga menjadi faktor yang turut mempengaruhi efektivitas Diklat karena pengajar yang membosankan dalam memberikan pelajaran tidak berbeda dengan buku pegangan atau bahan tulis lainya (Moekijat, 1991). Pengajar pada pendidikan dan latihan adalah orang yang menggerakkan semua komponen yang terlibat dalam 
proses pembelajaran. Proses belajar mengajar dapat berjalan ke arah interaksi yang komunikatif antara pengajar dengan peserta Diklat sehingga tercipta suasana belajar yang menyenangkan. Oleh karena itu pengajar perlu memiliki ketrampilan yang sesuai dengan kompetensi pendidikannya.

Faktor lain yang mempengaruhi efektivitas adalah pemanfaatan peserta setelah mereka selesai mengikuti pendidikan dan latihan itu. Sebab tidak sedikit pimpinan instansi yang kurang memberikan peluang untuk melaksanakan teori, keahlian, dan ketrampilan yang diperoleh selama Diklat itu. Bahkan pimpinan sering tidak menanyakan hasil Diklat itu (Nawawi, 2000).

Apabila pimpinan instansi memberikan dukungan dan kesempatan untuk menerapkan hasil Diklat, maka dapat diasumsikan bahwa kegiatan ini akan menghasilkan Diklat yang efektif:

Faktor-faktor tersebut sangat berpengaruh terhadap efektivitas Diklat Penyetaraan yang ditandai dengan peningkatan ketrampilan, pengetahuan, dan perubahan sikap/ kinerja peserta. Peningkatan ketrampilan/peserta dalam hal kegiatan perpustakaan seperti pengolahan bahan pustaka, administrasi, pelayanan jasa perpustakaan, dan lainnya. Kegiatan yang dapat diamati terhadap peningkatan pengetahuan peserta dalam bekerja lebih baik, lebih rasional, lebih teratur, dan lebih efisien. Sedangkan perubahan sikap/ kinerja peserta yang diwujudkan dalam perubahan tingkah laku seperti disiplin, kerjasama dengan teman sekerja, dan bertaggung jawab terhadap tugas yang diberikan.

\section{METODE PENELITIAN}

Metode penelitian yang digunakan adalah penelitian deskriptif yang menurut Surakhmad (1990) adalah penafsiran memutuskan data yang ada atau memusatkan diri pada pemecahan masalah-masalah yang ada pada masa sekarang. Penelitian deskriptif tidak melakukan pengujian hipotesa
(Singarimbun, 1995). Populasi penelitian adalah peserta Diklat Penyetaraan Pustakawan pada Perpustakaan Nasional Provinsi Kalimantan Selatan tahun 1999/2000 dan tahun 2000 sebanyak 53 orang dan pimpinan lembaga/instansi pengirim sebanyak 43 orang. Semua populasi dijadikan sampel penelitian karena jumlah populasi kurang dari 100 orang. Untuk keperluan bahan uji/check and re-check terhadap pernyataan responden dicek silang dengan tanggapan teman kerja peserta sebanyak 53 orang. Data utama didapatkan dari kuesioner, sedangkan data sekunder dikumpulkan dengan mempelajari dokumen berupa laporan panitia, data peserta, dan bahan lainnya yang relevan dengan penelitian ini baik yang berasal dari panitia maupun lembaga Perpustakaan Nasional Provinsi Kalimantan Selatan.

HASIL DAN PEMBAHASAN UMT PERMUSTAKAHW

Salah satu tujuan penelitian ini adalah untuk mengetahui efektivitas Diklat Penyetaraan Pustakawan. Kriteria efektif pada setiap indikator penelitian didasarkan pada data kuantitatif yang didapat dari hasil frekuensi dan persentase yang berasal dari pernyataan responden didasarkan pada kriteria $0-60 \%$ tidak efektif, dan $61-1005$ berarti efektif.

Dari informasi yang dihimpun melalui latar belakang 53 orang peserta, ditemukan $28,3 \%$ peserta tidak terpenuhi persyaratan pendidikan dari yang seharusnya untuk mengikuti Diklat ini yakni minimal Diploma II nonperpustakaan, $28.3 \%$ tersebut berpendidikan SLTA, sedangkan dari latar belakang status kepegawaian peserta ditemukan $33.9 \%$ peserta bukan berstatus Pegawai Negeri Sipil dan sebanyak $33.9 \%$ berstatus pegawai swasta. Dengan demikian, syarat yang dapat dipenuhi dari atar belakang pendidikan peserta hanya $71.7 \%$ da dari laatr belakang status kepegawaian peserta hanya $66.1 \%$ yang terpenuhi, berdasarkan prosentase yang didapat dari latar belakang 
peserta dinilai efektif.

Hasil persepsi responden terhadap efektivitas Diklat dengan indikator peningkatan ketrampilan, pengetahuan, dan perubahan kinerja peserta.Menurut persepsi peserta dinyatakan bahwa $54.7 \%$ peserta menyatakan ketrampilannya meningkat, tetapi prosentasenya tergolong tidak efektif. Sedangkan menurut persepsi pimpinan instansi pengirim dinyatakan efektif $(93.0 \%)$ dari peningkatan pengetahuan menurut persepsi peserta $49.0 \%$ peserta menyatakan meningkat tetapi tidak efektif, dari pernyataan pimpinan instansi pengirim pada indikator ini dinyatakan efektif (97.6 $\%)$. Pada indikator perubahan kinerja menurut persepsi peserta dinyatakan efektif (77.3\%) dan hal ini didukung oleh pernyataan efektif ( $90.6 \%)$. Berdasarkan masukan data tersebut ternyata ada dua indikator yang tidak efektif menurut persepsi peserta, sedangkan menurut pimpinan instansi pengirim dinyatakan ketiga indikator tersebut efektif. Perbedaan ini disebabkan oleh persepsi peserta dari $54.7 \%$ masih ada yang menyatakan bahwa ketrampilan mereka dalam melakukan pengolahan bahan pustaka, administrasi perpustakaan dan pelayanan belum meningkat, sedangkan pada indikator peningkatan pengetahuan dari $49.0 \%$ peserta masih ada yang menyatakan bahwa pengetahuan mereka belum meningkat secara signifikan Karena materi yang disajikan terlalu teoritis. Dengan pernyataan ini menurut persepsi peserta Diklat ini tidak efektif. Sedangkan menurut pimpinan instansi pengirim Diklat ini dinyatakan efektif.

Efektivitas Diklat di atas dipengaruhi oleh komponenkomponen Diklat seperti kesesuaian kurikulum, kemampuan pengajar, dan pemanfaatan peserta. Ketiga indikator ini menurut persepsi peserta juga belum sepenuhnya efektif. Dari indikator kesesuaian kurikulum $64.0 \%$ peserta menyatakan sangat sesuai. Analisis terhadap Rumusan Pembelajaran Khusus/RPK sebagai dasar pembelajaran dalam Diklat menunjukkan bahwa ditemukan 61.4\% RPKnya masih menitikberatkan pada aspek pengetahuan. Hanya $27.5 \%$ RPKnya yang mengarah pada peningkatan ketrampilan peserta seperti yang dikehendaki oleh tujuan dari setiap penyelenggaraa Diklat. Dengan demikian, efektivitas Diklat yang dipengaruhi oleh kesesuaian kurikulum ini dinyatakan efektif.

Pada indikator kemampuan pengajar, para pengajar dalam menyampaikan materi Diklat menurut persepsi perserta dinyatakan cukup mampu (75.4\%) dan dinilai efektif. Pernyataan cukup mampu ini tidak didukung dengan kompetensi para pengajar Diklat dari 22 orang pengajar hanya ada $18.1 \%$ yang berlatar belakang pendidikan sarjana strata satu (S1) ilmu Perpustakaan. Selebihnya hanya berlatar belakang sarjana administrasi negara, teknik, pendidikan, komunikasi, dan diploma perpustakaan.

Indikator lainnya yang dipersepsi peserta dan pimpinan instansi pengirim adalah pemanfaatan peserta. Pada indikator ini menurut pernyataan peserta $54.7 \%$ menyatakan cukup dimanfaatkan berarti tidak efektif, sedangkan menurut pimpinan instansi pengirim kehadiran peserta setelah mengikuti Diklat ini dinyatakan sangat dimanfaatkan (83.7\%) berarti efektif.

Dengan demikian, pernyataan peserta terhadap ketiga indikator ini dinilai efektif. Hal ini senada dengan persepsi yang diberikan oleh pimpinan instansi pengirim yang juga menyatakan efektif. Berbagai indikator yang diuraikan di atas, baik dari variabel terikat maupun variabel bebas setelah dicek silang dengan pernyataan teman kerja peserta ternyata menurut persepsi teman kerja peserta semua indikator yang ada dinilai efektif.

Diklat Penyetaraan Pustakawan yang bertujuan untuk meningkatkan jumlah pustakawan dari PNS, berlatar belakang pendidikan non perpustakaan minimal Diploma 2 telah tercapai. Hal ini didasarkan pada pernyataan peserta $77.3 \%$ peserta menyatakan siap memasuki Jabatan Fungsional 
Pustakawan. Pernyataan ini didukung oleh pengakuan pimpinan instansi pengirim sebanya $93.5 \%$ yang menyatakan peserta layak diusulkan dalam jabatan tersebut. Demikian pula halnya dengan pernyataan teman kerja peserta sebanyak 69.8 $\%$ mendukung usulan tersebut. Hal ini didukung oleh fakta pada Lapran Tahunan Perpustakaan Nasional Provinsi Kalimantan Selatan tahu anggaran 2000 menyatakan terdapat penambahan pustakawan baru sebanyak $26 \%$ dari lulusan Diklat tersebut.

Hasil penelitian tersebut menunjukkan bahwa rumusan penelitian yang berbunyi apakah hasil Diklat berpengaruh terhadap peningkatan ketrampilan, pengetahuan, dan perubahan kinerja peserta telah terjawab. Yakni bahwaDiklat ini tidak efektif menurut persepsi peserta, dan dinyatakan efektif menurut pimpinan lembaga instansi pengirim. Pernyataan efektif ini juga didukung oleh persepsi yang diberikan oleh teman kerja peserta.

Pernyataan peserta yang menilai Diklat ini tidak fektif menunjukkan bahwa Diklat ini belum secara signifikan dapat meningkatkan ketrampilan dan pengetahuan mereka dengan alasan peserta belum mampu melaksanakan tugas-tugas kepustakawanan dengan lancar dan materi pelajaran dinilai masih terlalu teoritis.

\section{KESIMPULAN}

Berdasarkan pembahasan dan hasil analisis tersebut dapat disimpulkan bahwa:

1. Diklat Peyetaraan Pustakawan yang diselenggarakan oleh Perpustakaan Nasional Provinsi Kalimantan Selatan menurut persepsi peserta dinyatakan tidak efektif, sedangkan menurut pimpinan instansi pengirim dinyatakan efektif.

2. Pada indikator yang dapat mempengaruhi efektivitas Diklat juga terdapat perbedaan persepsi atara persepsi peserta dan pimpinan instansi pengirim.
3. Diklat Penyetaraan Pustakawan yang bertujuan untuk memberikan sertifikasi atau penyetaraan kepada peserta yang berlatar belakang pendidikan non perpustakaan untuk diangkat sebagai pejabat Jabatan Fungsional Asisten Pustakawan dan Pustakawan dinilai efektif.

\section{DAFTARPUSTAKA}

Drever, James. 1988. Kamus Psikologi. Jakarta: Bina Aksara Hernandono. 1999. Perkembangan Sumber Daya Perpustakaan Untuk Mengantisipasi Milenium III. Makalah Temu Karya FKP2T di UNDIP Semarang

Kartono, Kartini. 1990. Psikologi Umum. Bandung Mandar Maju

Mahladi. 2000. Membuat Perpustakaan Seperti Musik Dangdut. Republika, 21 Mei 2000

Moekijat. 1991. Latihan dan Pengembangan Sumber Daya Manusia. Bandung: Mandar Maju

Nawawi, Hadari. 2000. Manajemen Sumber Daya Manusia Untuk Bisnis Yang Kompetitif. Yogyakarta: Gadjah Mada University Press

Perpustakaan Nasional RI. 1998. Keputusan Kepala Perpustakaan Nasional RI Nomor 44 tahun 1998 tentang Organisasi dan Tata Kerja Perpustakaan Nasional RI. Jakarta: Perpustakaan Nasional RI.

-_ 1999. Keputusan Kepala Perpustakaan Nasional RI Nomor 72 tahun 1999 tentang Petunjuk Teknis Jabatan Fungsional Pustakawan dan Angka Kreditnya. Jakarta: Perpustakaan Nasional RI

Rahmania. 1999. Efektivitas Program Pendidikan Guru SD di Fakultas Keguruan dan Ilmu Pendidikan Universitas Haluoleo Kendari. Tesis Pascasarjana Universitas Negeri Yogyakara

Singarimbun, Masri; Sofian Effendi. 1995. Metode Penelitian Survei. Jakarta: LP3ES

Surakhmad, Winarno. 1990. Pengantar Penelitian Ilmiah Dasar; Metode dan Teknis. Bandung: Tarsito. 